\title{
Evaluation of pH, titratable acidity, syneresis and sensory profiles of some yoghurt samples from the Kingdom of Lesotho
}

\author{
Matela, K.S., *Pillai, M.K. and Thamae, T. \\ Department of Chemistry and Chemical Technology, Faculty of Science and Technology, National \\ University of Lesotho, Roma Campus, P. O. Roma 180, Kingdom of Lesotho, Southern Africa
}

\author{
Article history: \\ Received: 28 April 2019 \\ Received in revised form: 30 \\ May 2019 \\ Accepted: 31 May 2019 \\ Available Online: 5 June \\ 2019
}

\section{Keywords:}

$\mathrm{pH}$,

Titratable acidity,

Syneresis,

Sensory profiles,

Yoghurt,

Kingdom of Lesotho

DOI:

https://doi.org/10.26656/fr.2017.3(6).177

\begin{abstract}
A total of nine yoghurt samples purchased from the Kingdom of Lesotho were evaluated for their $\mathrm{pH}$, titratable acidity, syneresis and sensory profiles following standard procedures. The $\mathrm{pH}$, titratable acidity and syneresis of these nine samples were found to be in the range of $3.94-4.22,0.69-1.81$ and $1.76-35.15 \%$, respectively. The sensory profiles such as appearance, texture, aroma, flavour, taste and overall acceptability of these nine samples were found to be in the range of 2.5-4.5, 2.2-3.3, 2.5-4.1, 1.7-4.0, 2.1-4.3 and 2.33.9 , respectively. The $\mathrm{pH}$ of all nine yoghurt samples was complying in accordance with FDA specifications. The percentages of titratable acidity of some yoghurt samples were complying in accordance with FDA specifications and some samples were not. On the other hand, some samples have remarkably high syneresis. Our study showed that the $\mathrm{pH}$, titratable acidity, syneresis and sensory profiles of these yoghurt samples were significantly different $(\mathrm{p}<0.05)$. Sensory properties, particularly, flavour, taste and aroma of yoghurt samples are needed to be improved for a better consumer overall acceptability. To the best of our knowledge, this is the first report of this kind on yoghurt samples from the Kingdom of Lesotho.
\end{abstract}

\section{Introduction}

Probiotics are defined as live active microorganisms which upon ingestion in sufficient number could improve intestinal microbial balance and therefore, they will enhance the health of the host (Ndife et al., 2014). Yoghurts are acting as probiotic carriers. Yoghurts have nutritionally rich fat, high level of biologically important protein, calcium, zinc, potassium, magnesium, phosphorus, riboflavin (vitamin $\mathrm{B}_{2}$ ), thiamine (vitamin $\mathrm{B}_{1}$ ), vitamin $\mathrm{B}_{6}$, vitamin $\mathrm{B}_{12}$, niacin and are also a good source of folate (Mckinley, 2005; Oladipo et al., 2014; Ndife et al., 2014; El-Abbadi et al., 2014). The minerals and vitamins found in yoghurts are bioavailable that is they are easily accessible such that the body could easily absorb and use. Yoghurts also provide the bioavailable protein of high quality. Yoghurts contain almost all essential amino acids necessary to maintain good health; particularly they have a higher content of amino acids such as proline and glycine compared to the whole milk (Mckinley, 2005).

Yoghurts are produced by anaerobic fermentation of lactose present in the milk. Lactose is converted into lactic acid through the action of some bacterial cultures. In the modern days, a starter culture of a combination of
Streptococcus thermophilus and Lactobacillus delbrueckii ssp. bulgaricus has been used to produce yoghurts. The combination of these two cultures has some symbiotic relationship. S. thermophiles produce folic acid, formic acid, $\mathrm{CO}_{2}$, etc. in the initial stage. The production of these chemicals promotes the growth of $L$. delbrueckii ssp. bulgaricusis. On the other hand, $L$. delbrueckii ssp. bulgaricus produces free amino acids and small peptides, which help with the growth of $S$. thermophilus (Aswal et al., 2012). Overall, this combination of culture has some advantages that it could produce lactic acid more rapidly than in a single strain culture alone (Aswal et al., 2012; Horackova et al., 2015). However, the use of traditional cultures such as Lactobacillus helveticus, Lactobacillus delbrueckii spp. lactis etc. are also not uncommon in some countries (Mckinley, 2005). The use of these traditional cultures has some advantages that it can grow even at low $\mathrm{pH}$ and their growth is not affected by acidity (Aswal et al., 2012; Corrieu and Beal, 2016; Mbaeyi-Nwaoha et al., 2017). Our literature search showed that $\mathrm{pH}$, titratable acidity, syneresis and sensory profiles of yoghurt samples from the Kingdom of Lesotho have not been reported previously. The aim of the present study was to evaluate the $\mathrm{pH}$, titratable acidity, syneresis and sensory 
profiles of nine commercially available yoghurt samples purchased from three manufacturers in the Kingdom of Lesotho, Southern Africa. The results obtained are communicated in this article. To the best of our knowledge, this is the first report of this kind on yoghurt samples from the Kingdom of Lesotho.

\section{Materials and methods}

\subsection{Determination of $\mathrm{pH}$}

The $\mathrm{pH}$ of yoghurt samples was determined by the method as described in the literature (Igbabul et al., 2014). Briefly, $10 \mathrm{~g}$ of yoghurt sample was dissolved in $100 \mathrm{~mL}$ of distilled water. The mixture was allowed to equilibrate at room temperature. The $\mathrm{pH}$ of the samples was then determined by a $\mathrm{pH}$ meter (HANNA, Italy).

\subsection{Determination of titratable acidity}

Titratable acidity was determined by the method described by Oladipo et al. (2014). Briefly, $10 \mathrm{~g}$ of the sample was dissolved in $30 \mathrm{~mL}$ of distilled water and mixed thoroughly. A few drops of phenolphthalein indicator were added in the mixed solution. It was titrated against standard $0.1 \mathrm{~N}$ sodium hydroxide solution until a pale pink colour was persisted for about 10-15 seconds for complete neutralization. The titratable acidity was calculated based on lactic acid which is the main organic acid in yoghurt samples and is given in the equation below.

Titratable acidity $(\%)=\frac{\text { Vol. } \mathrm{NaOH} \text { used }(\mathrm{ml}) \times 0.1 \mathrm{~N} \mathrm{NaOH} \times \text { milliequivalent factor } \times 100}{\text { mass of sample }(\mathrm{g})}$

\subsection{Determination of syneresis of yoghurt}

The degree of syneresis is expressed as the proportion of free whey (i.e. the spontaneous release of the watery part of yoghurts due to gel contraction). It was measured by the method described by Wijesinghe et al. (2018). Briefly, $10 \mathrm{~g}$ of each yoghurt sample was placed separately on a filter paper and was allowed to rest on the top of a funnel. After 10 mins of drainage in vacuum condition, the quantity of remaining yoghurt was weighed and the syneresis was calculated by the equation given below.

Free whey $(\%)=\frac{\text { weight of initial sample-weight of sample after filtration } \times 100}{}$

\subsection{Sensory evaluation}

The organoleptic characteristics such as appearance, aroma, flavour, taste, texture and overall acceptability of yoghurt were evaluated according to the method described by Olugbuyiro and Oseh (2011). The samples were evaluated by the 15 panellists that comprised of undergraduate students (4), postgraduate students (4), lecturers (3) and non-teaching staff members (4) of National University of Lesotho, Roma campus, Kingdom of Lesotho. The samples were evaluated using a ninepoint hedonic scale. Score $=1$ has been assigned for "like extremely" and score $=9$ has been assigned for "dislike extremely".

\subsection{Statistical analysis}

Analysis was done in triplicate and the results were expressed as means. One-way analysis of variance (ANOVA) was used to compare means at the significant level $p<0.05$. All analyses were performed by Microsoft Excel software.

\section{Results and discussion}

Table 1. The percentage of physiochemical properties of nine yoghurt samples.

\begin{tabular}{cccc}
\hline Samples & $\mathrm{pH}$ & Titratable Acidity (\%) & Syneresis (\%) \\
\hline $\mathrm{Y}_{1}$ & $4.22 \pm 0.01^{\mathrm{a}}$ & $0.69 \pm 0.04^{\mathrm{a}}$ & $2.29 \pm 0.28^{\mathrm{ad}}$ \\
$\mathrm{Y}_{2}$ & $4.20 \pm 0.01^{\mathrm{b}}$ & $0.79 \pm 0.01^{\mathrm{a}}$ & $3.26 \pm 0.41^{\mathrm{ab}}$ \\
$\mathrm{Y}_{3}$ & $4.12 \pm 0.01^{\mathrm{c}}$ & $0.76 \pm 0.03^{\mathrm{bc}}$ & $3.20 \pm 0.02^{\mathrm{bc}}$ \\
$\mathrm{Y}_{4}$ & $4.02 \pm 0.01^{\mathrm{d}}$ & $0.70 \pm 0.03^{\mathrm{ac}}$ & $1.76 \pm 0.71^{\mathrm{acd}}$ \\
$\mathrm{Y}_{5}$ & $3.97 \pm 0.01^{\mathrm{e}}$ & $0.70 \pm 0.01^{\mathrm{a}}$ & $3.11 \pm 0.20^{\mathrm{d}}$ \\
$\mathrm{Y}_{6}$ & $3.99 \pm 0.01^{\mathrm{f}}$ & $0.79 \pm 0.02^{\mathrm{h}}$ & $3.76 \pm 0.94^{\mathrm{ad}}$ \\
$\mathrm{Y}_{7}$ & $4.00 \pm 0.02^{\mathrm{df}}$ & $1.37 \pm 0.03^{\mathrm{d}}$ & $35.15 \pm 0.07^{\mathrm{f}}$ \\
$\mathrm{Y}_{8}$ & $3.94 \pm 0.01^{\mathrm{g}}$ & $1.68 \pm 0.18^{\mathrm{e}}$ & $32.62 \pm 2.19^{\mathrm{g}}$ \\
$\mathrm{Y}_{9}$ & $3.94 \pm 0.01^{\mathrm{g}}$ & $1.81 \pm 0.02^{\mathrm{e}}$ & $29.34 \pm 3.73^{\mathrm{h}}$ \\
\hline
\end{tabular}

Values are expressed as mean \pm SD of triplicate determination. Different alphabet superscript within the same column are significantly different $(\mathrm{p}<0.05)$.

A total of nine yoghurt samples viz. $\left(\mathrm{Y}_{1}, \mathrm{Y}_{2}\right.$, and $\left.\mathrm{Y}_{3}\right)$, $\left(\mathrm{Y}_{4}, \mathrm{Y}_{5}\right.$, and $\left.\mathrm{Y}_{6}\right)$ and $\left(\mathrm{Y}_{7}, \mathrm{Y}_{8}\right.$ and $\left.\mathrm{Y}_{9}\right)$ were purchased in a local market in the Kingdom of Lesotho, Southern Africa, from manufacturers 1, 2 and 3, respectively. The physiochemical properties viz. $\mathrm{pH}$, the percentage of titratable acidity and the percentages of syneresis of various yoghurt samples are summarised in Table 1 . The $\mathrm{pH}$ values were found to be 4.22, 4.20, 4.12, respectively, for $\mathrm{Y}_{1}, \mathrm{Y}_{2}$, and $\mathrm{Y}_{3} ; 4.02,3.97$ and 4.00, respectively for $\mathrm{Y}_{4}, \mathrm{Y}_{5}$ and $\mathrm{Y}_{6}$; and 4.00, 3.94 and 3.94, respectively for $Y_{7}, Y_{8}$ and $Y_{9}$. Although all nine samples showed comparable $\mathrm{pH}$ values, $\mathrm{Y}_{8}$ and $\mathrm{Y}_{9}$ have the lowest $\mathrm{pH}$ value of 3.94 while $\mathrm{Y}_{1}$ has the highest $\mathrm{pH}$ value of 4.22. The $\mathrm{pH}$ of all the yoghurt samples complied with Food and Drug Administration (FDA) specifications which state that yoghurt should have a maximum pH of 4.5 (Weerathilake et al., 2014). The low $\mathrm{pH}$ value would be the result of amount of lactic acid produced from the fermentation of milk lactose by bacteria (Oladipo et al., 2014). Due to the low $\mathrm{pH}$ value of yoghurt, calcium would be converted to its ionic form making it highly bioavailable for intestinal absorption. Additionally, the inhibitory effect of dietary phytic acid on calcium bioavailability would be reduced by the low 
Table 2. The average point score of various sensorial profiles of nine yoghurt samples.

\begin{tabular}{ccccccc}
\hline Samples & Appearance & Aroma & Flavour & Taste & Texture & Overall Acceptability \\
\hline $\mathrm{Y}_{1}$ & $2.9 \pm 1.6^{\mathrm{a}}$ & $2.7 \pm 1.2^{\mathrm{a}}$ & $3.0 \pm 1.4^{\mathrm{abd}}$ & $2.9 \pm 1.3^{\mathrm{ac}}$ & $2.2 \pm 1.0^{\mathrm{a}}$ & $3.1 \pm 1.3^{\mathrm{abc}}$ \\
$\mathrm{Y}_{2}$ & $3.1 \pm 1.7^{\mathrm{a}}$ & $3.0 \pm 1.2^{\mathrm{ac}}$ & $2.9 \pm 1.6^{\mathrm{abd}}$ & $3.3 \pm 2.2^{\mathrm{abc}}$ & $3.1 \pm 1.7^{\mathrm{ab}}$ & $3.1 \pm 1.7^{\mathrm{abc}}$ \\
$\mathrm{Y}_{3}$ & $2.9 \pm 1.8^{\mathrm{a}}$ & $3.0 \pm 1.2^{\mathrm{ac}}$ & $3.2 \pm 1.8^{\mathrm{abd}}$ & $2.7 \pm 1.5^{\mathrm{a}}$ & $2.7 \pm 1.4^{\mathrm{ab}}$ & $3.0 \pm 1.7^{\mathrm{abc}}$ \\
$\mathrm{Y}_{4}$ & $2.8 \pm 1.9^{\mathrm{a}}$ & $2.5 \pm 1.2^{\mathrm{a}}$ & $1.7 \pm 1.1^{\mathrm{c}}$ & $2.1 \pm 1.4^{\mathrm{a}}$ & $2.3 \pm 1.4^{\mathrm{a}}$ & $2.3 \pm 1.3^{\mathrm{a}}$ \\
$\mathrm{Y}_{5}$ & $2.9 \pm 1.7^{\mathrm{a}}$ & $2.5 \pm 1.1^{\mathrm{a}}$ & $2.5 \pm 1.2^{\mathrm{a}}$ & $2.3 \pm 1.0^{\mathrm{a}}$ & $2.7 \pm 1.5^{\mathrm{ab}}$ & $2.7 \pm 1.2^{\mathrm{ab}}$ \\
$\mathrm{Y}_{6}$ & $2.7 \pm 1.2^{\mathrm{a}}$ & $2.7 \pm 0.8^{\mathrm{a}}$ & $2.7 \pm 1.3^{\mathrm{ab}}$ & $2.7 \pm 1.3^{\mathrm{a}}$ & $2.9 \pm 1.2^{\mathrm{ab}}$ & $2.8 \pm 1.0^{\mathrm{ab}}$ \\
$\mathrm{Y}_{7}$ & $2.5 \pm 1.5^{\mathrm{a}}$ & $4.1 \pm 1.4^{\mathrm{bc}}$ & $3.8 \pm 1.7^{\mathrm{bd}}$ & $4.1 \pm 1.6^{\mathrm{b}}$ & $2.9 \pm 1.7^{\mathrm{ab}}$ & $3.7 \pm 1.5^{\mathrm{bc}}$ \\
$\mathrm{Y}_{8}$ & $3.5 \pm 2.0^{\mathrm{ab}}$ & $3.9 \pm 1.6^{\mathrm{c}}$ & $3.9 \pm 1.9^{\mathrm{d}}$ & $4.3 \pm 1.8^{\mathrm{b}}$ & $3.1 \pm 1.5^{\mathrm{ab}}$ & $3.9 \pm 1.6^{\mathrm{c}}$ \\
$\mathrm{Y}_{9}$ & $4.5 \pm 1.8^{\mathrm{b}}$ & $4.1 \pm 1.5^{\mathrm{c}}$ & $4.0 \pm 1.4^{\mathrm{d}}$ & $4.0 \pm 1.8^{\mathrm{bc}}$ & $3.3 \pm 1.2^{\mathrm{b}}$ & $3.9 \pm 1.2^{\mathrm{c}}$ \\
\hline
\end{tabular}

Values are expressed as mean \pm SD of triplicate determination. Different alphabet superscript within the same column are significantly different $(\mathrm{p}<0.05)$.

$\mathrm{pH}$ value of yoghurt (Adolfsson et al., 2004). The low $\mathrm{pH}$ value of yoghurts also inhibits the growth of pathogens present in the yoghurts (Mbaeyi-Nwaoha et al., 2017).

The titratable acidity is expressed as percentage of lactic acid present in the yoghurt samples. The percentage of titratable acidity were found to be $0.69 \%$, $0.79 \%$ and $0.76 \%$, respectively, for $\mathrm{Y}_{1}, \mathrm{Y}_{2}$ and $\mathrm{Y}_{3}$; $0.70 \%, 0.70 \%$ and $0.79 \%$, respectively for $\mathrm{Y}_{4}, \mathrm{Y}_{5}$ and $\mathrm{Y}_{6}$; and $1.37 \%, 1.68 \%$ and $1.81 \%$, respectively for $\mathrm{Y}_{7}, \mathrm{Y}_{8}$ and $\mathrm{Y}_{9}$. The samples $\mathrm{Y}_{7}, \mathrm{Y}_{8}$, and $\mathrm{Y}_{9}$ have remarkably high titratable acidity relative to other samples and this could be due to more availability of fermenting microbes. Among these nine samples, only $\mathrm{Y}_{7}, \mathrm{Y}_{8}$, and $\mathrm{Y}_{9}$ complied with FDA specification which states that yoghurts should have a minimum titratable acidity of 0.9\% (Weerathilake et al., 2014).

The syneresis was found to be $2.29 \%, 3.26 \%$, and $3.20 \%$, respectively for $\mathrm{Y}_{1}, \mathrm{Y}_{2}$ and $\mathrm{Y}_{3} ; 1.76 \%, 3.11 \%$ and $3.76 \%$, respectively for $\mathrm{Y}_{4}, \mathrm{Y}_{5}$ and $\mathrm{Y}_{6}$ and $35.15 \%$, $32.62 \%$ and $29.34 \%$, respectively for $\mathrm{Y}_{7}, \mathrm{Y}_{8}$ and $\mathrm{Y}_{9}$. $\mathrm{Y}_{7}$, $\mathrm{Y}_{8}$, and $\mathrm{Y}_{9}$ samples exhibited relatively high syneresis compared to other samples. The main causes of syneresis are low solid content, use of high temperatures during incubation, inadequate storage temperatures, high acidity, etc. (Jambi, 2018). Wijesinghe et al. (2018) stated that the stabiliser present in the yoghurt samples binds free water molecule and trap it in the casein network. As a result of this action, the viscosity of the sample will increase and subsequently syneresis will decrease. Yoghurt with high syneresis is a negative characteristic which could lead to rejection by consumers (Moreno-Montoro et al., 2018). This is reflected in our findings that the overall acceptability of $\mathrm{Y}_{7}, \mathrm{Y}_{8}$ and $\mathrm{Y}_{9}$ samples received high scores, which indicated less desirable trait by panellists.

All nine yoghurt samples were also evaluated for their sensorial profiles such as appearance, flavour, taste, aroma and overall acceptance. The results obtained are summarised in Table 2. The lowest number represents the most desirable traits and the highest number represents the least desirable traits. In other words, score $=1$ has been assigned for "extremely like" and score $=9$ has been assigned for "extremely dislike" (9). Therefore, a score of 5 represents neither like or dislike. The average point score for "appearance" were found to be 2.9, 3.1 and 2.9, respectively, for $\mathrm{Y}_{1}, \mathrm{Y}_{2}$ and $\mathrm{Y}_{3} ; 2.8,2.9$ and 2.7, respectively for $\mathrm{Y}_{4}, \mathrm{Y}_{5}$ and $\mathrm{Y}_{6}$; and 2.5, 3.5 and 4.5, respectively for $Y_{7}, Y_{8}$ and $Y_{9}$. Therefore, for "appearance", $\mathrm{Y}_{7}$ received the lowest score of 2.5 while $\mathrm{Y}_{9}$ received the highest score of 4.5. The "appearance" was influenced by the colour of the yoghurt and the panellists showed preference for a brighter pinkish colour of $\mathrm{Y}_{7}$. The average point score for "aroma" were found to be 2.7, 3.0 and 3.0, respectively of $Y_{1}, Y_{2}$ and $\mathrm{Y}_{3} ; 2.5,2.5$ and 2.7, respectively for $\mathrm{Y}_{4}, \mathrm{Y}_{5}$ and $\mathrm{Y}_{6}$ and 4.1, 3.9 and 4.1, respectively for $\mathrm{Y}_{7}, \mathrm{Y}_{8}$ and $\mathrm{Y}_{9}$. The average point score for "flavour" were found to be 3.0, 2.9 and 3.2, respectively for $\mathrm{Y}_{1}, \mathrm{Y}_{2}$ and $\mathrm{Y}_{3} ; 1.7,2.5$ and 2.7, respectively for $Y_{4}, Y_{5}$ and $Y_{6}$ and 3.8, 3.9 and 4.0, respectively for $Y_{7}, Y_{8}$ and $Y_{9}$. $Y_{4}$ received the lowest score of 2.5 and 1.7 for "aroma and flavour", respectively, while $\mathrm{Y}_{9}$ received the highest score of 4.1 and 4.0, respectively. Eleven panellists accepted $\mathrm{Y}_{4}$ due to its sweetness. The addition of flavour not only gives a wide array of tastes but also increases the sweetness of yoghurt (Weerathilake et al., 2014). Ndife et al. (2014) reported that fat content has a considerable impact on both instrumental and sensory characteristics of yoghurts. The reason for this fact is that fat has better rheology and it acts as an aroma solvent compared to skimmed and low-fat yoghurt. The aroma of yoghurt is produced by about hundreds of volatile compounds which consists of alcohols, carbonyl compounds (mainly acids and esters), and heterocyclic and sulphurcontaining compounds. However, among these volatile compounds, acetaldehyde is the major flavour compound of yoghurt which gives pleasant, fresh and fruity aroma. 
The low flavour values could be due to the high content of carbohydrate which increases the sweetness of yoghurt (Ndife et al., 2014; Corrieu and Beal, 2016).

The average point score for "taste" was found to be 2.9, 3.3 and 2.7, respectively for $Y_{1}, Y_{2}$ and $Y_{3} ; 2.1,2.3$ and 2.7, respectively for $Y_{4}, Y_{5}$ and $Y_{6}$ and 4.1, 4.3 and 4.0, respectively, for $Y_{7}, Y_{8}$ and $Y_{9}$. Sample $Y_{4}$ was most preferred by panellists since it received a point score of 2.1 while $\mathrm{Y}_{8}$ was least preferred since it received a point score of 4.3. $\mathrm{Y}_{4}$ was found to be sweetest among all yoghurt samples. Weerathilake et al. (2014) pointed out that the preference for certain yoghurt taste is attributable to its sweetness. The sensory scores for "texture" relate to mouthfeel, oral viscosity and consistency of yoghurts. The average point score for "texture" was found to be 2.2, 3.1 and 2.7, respectively for $Y_{1}, Y_{2}$ and $Y_{3} ; 2.3,2.7$ and 2.9, respectively for $\mathrm{Y}_{4}, \mathrm{Y}_{5}$ and $\mathrm{Y}_{6}$; and 2.9, 3.1 and 3.3 , respectively for $Y_{7}, Y_{8}$ and $Y_{9} . Y_{9}$ received the highest score of 3.3 compared to other yoghurts and this may be attributed mainly due to their poor consistency (watery nature). $\mathrm{Y}_{1}$ received the lowest score of 2.2 and this may be attributed mainly due to its high viscosity. The panellists appreciated the increased viscosity as it makes yoghurt chewable before swallowing (Corrieu and Beal, 2016). Even though appearance, texture and thickness are very important characteristics to contribute the quality of yoghurt, the flavour is generally considered as the most important of all and critical indicator of consumer acceptability (Olugbuyiro and Oseh, 2011). Our findings confirmed the aforementioned statement such that the flavour, taste and aroma had a very strong influence in overall acceptability of yoghurts by the panellists. The average point score for "overall acceptability" was found to be 3.1, 3.1 and 3.0, respectively for $\mathrm{Y}_{1}, \mathrm{Y}_{2}$ and $\mathrm{Y}_{3} ; 2.3,2.7$ and 2.8, respectively for $\mathrm{Y}_{4}, \mathrm{Y}_{5}$ and $\mathrm{Y}_{6}$; and 3.7, 3.9 and 3.9, respectively for $Y_{7}$ and $Y_{8}$ and $Y_{9}$. Sample $Y_{4}$ received the lowest score of 2.3 which showed a direct relationship with its average scores of aroma, flavour and taste. $\mathrm{Y}_{8}$ and $\mathrm{Y}_{9}$ received the highest score of 3.9. Our study also showed that the sensory profiles of all nine evaluated yoghurt samples were found to be significantly different $(\mathrm{p}<0.05)$.

\section{Conclusion}

A total of nine commercially available yoghurt samples from the Kingdom of Lesotho, Southern Africa were analysed for their $\mathrm{pH}$, titratable acidity and syneresis and found to be in the range of 3.94-4.22, 0.691.81 and $1.76-35.15 \%$, respectively. Additionally, the sensory profiles such as appearance, texture, aroma, flavour, taste and overall acceptability of these samples were also analysed and found to be in the range of 2.5 -
$4.5,2.2-3.3,2.5-4.1,1.7-4.0,2.1-4.3$ and 2.3-3.9, respectively. The $\mathrm{pH}$ of all nine yoghurt samples was complying in accordance with FDA specifications. The percentages of titratable acidity of samples $\mathrm{Y}_{7}, \mathrm{Y}_{8}$ and $\mathrm{Y}_{9}$ were complying in accordance with FDA specifications and the rest of the samples were not. Additionally, these three samples, $\mathrm{Y}_{7}, \mathrm{Y}_{8}$ and $\mathrm{Y}_{9}$, have remarkably high titratable acidity and syneresis compared to other samples. Our findings showed that a pleasant flavour, taste and aroma have a very significant role in the overall acceptability of yoghurt samples. Therefore, the sensory properties, particularly, flavour, taste and aroma of yoghurt samples are needed to be improved for a better consumer overall acceptability.

\section{Conflict of Interest}

The authors declare no conflict of interest, financial or otherwise.

\section{Acknowledgements}

The authors would like to thank the National University of Lesotho for its support.

\section{References}

Adolfsson, O., Meydani, S.N. and Russell, R.M. (2004). Yogurt and gut function. The American Journal of Clinical Nutrition, 80(2), 245-256. https:// doi.org/10.1093/ajen/80.2.245

Aswal, P., Shukla, A. and Priyadarshi, S. (2012). Yoghurt: Preparation, characteristics and recent advancements. Cibtech Journal of Bio-Protocols, 1 (2), 32-44.

Corrieu, G. and Beal, C. (2016). Yoghurt: The product and its manufacture. In Caballero, B., Finglas, P. and Toldra, F. (Eds). The Encyclopaedia of Food and Health, p. 617-624. USA; Elsevier https:// doi.org/10.1016/B978-0-12-384947-2.00766-2

Donova, S.H. and Shamir, R. (2014). Introduction to the yoghurt in nutrition initiative and the first global summit on the effect of yoghurt. The American Journal of Clinical Nutrition, 99(5), 1209S-1211S. https://doi.org/10.3945/ajcn.113.073429

El-Abbadi, N.H., Dao, M.C. and Meydani, S.N. (2014). Yogurt: role in healthy and active aging. The American Journal of Clinical Nutrition, 99(Suppl.), 1263S-1270S. https://doi.org/10.3945/ ajcn.113.073957

Gahruie, H.H., Eskandari, M.H., Mesbahi, G. and Hanifpour, M.A. (2015). Scientific and technical aspects of yoghurt fortification: A review. Food Science and Human Wellness, 4(1), 1-8. https:// 
doi.org/10.1016/j.fshw.2015.03.002

Ghadge, P.N., Prasad, K. and Kadam, P.S. (2008). Effect of fortification on the physico-chemical and sensory properties of buffalo milk yoghurt. Electronic Journal of Environmental, Agricultural and Food Chemistry, 7(5), 2890-2899.

Horackova, S., Muhlhansova, A., Slukova, M., Schulzova, V. and Plockova, M. (2015). Fermentation of soymilk by yoghurt and bifidobacteria strains. Czech Journal of Food Sciences, 33, 313-319. https:// doi.org/10.17221/115/2015-CJFS

Igbabul, B., Shember, J. and Amove, J. (2014). Physicochemical, microbiological and sensory evaluation of yoghurt sold in Marurdi metropolis. African Journal of Food Science and Technology, 5 (6), 129-135

Jambi, H.A. (2018). Evaluation of physio-chemical and sensory properties of yoghurt prepared with date pits powder. Current Science International, 7(1), 1-9.

Mbaeyi-Nwaoha, I.E., Umeh, L.C., Igbokwe, C.J., Obodoechi, C.M. and Okoronkwo, N.C. (2017). Production and quality evaluation of flavoured yoghurt from graded levels of sweet variety of African bush mango "urigi" (Irvingia gabonensis) juice and pulp. Food Science and Technology, 5(2), 56-69.

Mckinley, M.C. (2005). The nutrition and health benefits of yoghurt. International Journal of Dairy Technology, 58(1), 1-12. https://doi.org/10.1111/ j.1471-0307.2005.00180.x

Moreno-Montono, M., Navarro-Alarcon, M., BergillosMeca, T., Gimenez-Martinez, R., SanchezHernandez, S. and Olalla-Herrera, M. (2018). Physicochemical, Nutritional, and organoleptic characterization of a skimmed goat milk fermented with the probiotic strain Lactobacillus plantarum $\mathrm{C} 4$. Nutrients, 10(5), 633-649. https://doi.org/10.3390/ nu10050633

Ndife, J., Idoko, F. and Garba, R. (2014). Production and quality assessment of function yoghurt enriched with coconut. International Journal of Nutrition and Food Sciences, 3(6), 545-550. https://doi.org/10.11648/ j.ijnfs.20140306.19

Obi, C.N., Olugbue, V.U. and Mpamugo, C.P. (2016). Yoghurt production from powdered milk using mixed lactic acid bacteria starter cultures. Saudi Journal of Pathology and Microbiology, 1(2), 42-49.

Oladipo, I.C., Atolagbe, O.O. and Adetiba, T.M. (2014). Nutrition evaluation and microbiological analysis of yoghurt produced from full cream milk, tiger-nut milk, skimmed milk and fresh cow milk. Pensee
Journal, 76(4), 30-38.

Olugbuyiro, J.A.O. and Oseh, J.E. (2011). Physicochemical and sensory evaluation of market yoghurt in Nigeria. Pakistan Journal of Nutrition, 10(10), 914-918. https://doi.org/10.3923/pjn.2011.914.918

Weerathilake, W.A.D.V., Rasika, D.M.D., Ruwanmali, J.K.U. and Munasinghe, M.A.D.D. (2014). The evolution, processing, varieties and health benefits of yogurt. International Journal of Scientific and Research Publications, 4(4), 1-10.

Wijesinghe, J.A.A.C., Wickramasinghe, I. and Saranandha, K.H. (2018). Optimizing organoleptic properties of drinking yoghurt incorporated with modified kithul (Caryota urens) flour as a stabilizer and evaluating its quality during storage. Vidyodaya Journal of Science, 21(1), 36-48. 